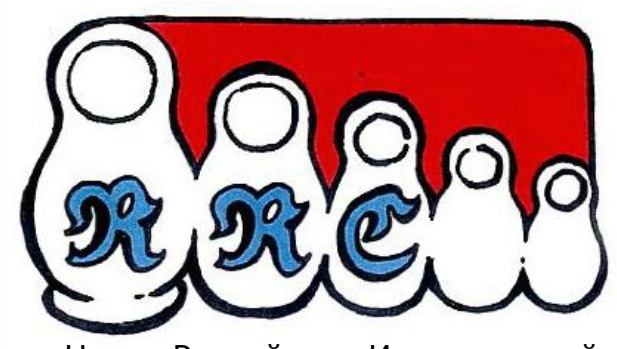

Центр Российских Исследований RRC Working Paper Series No. 32

Firm-Level Determinants of Board System Choice: Evidence from Russia

Ichiro IWASAKI

February 2013: revised version May 2011: first version

\author{
RUSSIAN RESEARCH CENTER \\ THE INSTITUTE OF ECONOMIC RESEARCH \\ HITOTSUBASHI UNIVERSITY \\ Kunitachi, Tokyo, JAPAN
}


RRC Working Paper No. 32

February 2013 [revised version; first published in May 2011]

\title{
Firm-Level Determinants of Board System Choice: Evidence from Russia
}

\section{Ichiro Iwasaki}

\author{
Russian Research Center \\ Institute of Economic Research, Hitotsubashi University \\ 2-1 Naka, Kunitachi City, Tokyo 186-8603, JAPAN \\ TEL.: +81-42-580-8366 / FAX: +81-42-580-8333 \\ E-mail: iiwasaki@ier.hit-u.ac.jp
}

\begin{abstract}
In this paper, using a unique dataset of joint-stock companies, we empirically examine the determinants of the choice and size of the collective executive board, a core element of the multi-tier board system of Russian firms. Our empirical evidence strongly suggests that the need of company executives for a collective management system is a key driver for the formation of a collective executive board, while outside investors are generally indifferent toward its adoption as a means to strengthening the monitoring and control functions over top management. We also found that Russian firms in the pursuit of the internationalization of their business activities tend to avoid the establishment of a collective executive board, which is a diverse corporate organ from the viewpoint of the international standard of corporate governance systems.
\end{abstract}

JEL classification numbers: D22, G34, K22, L22, P31, P34

Key words: board system choice, executive board, corporate governance, strategic management, Russia

\footnotetext{
* This paper is the product of a Japan-Russia joint research project entitled "Corporate Governance and Integration Processes in the Russian Economy" launched by the Institute of Economic Research, Hitotsubashi University (Tokyo), and the Institute for Industrial and Market Studies, State University - Higher School of Economics (Moscow). The research was financially supported by grants-in-aid for scientific research from the Ministry of Education and Sciences in Japan (Nos. 21402025 and 23243032) and the Joint Usage and Research Center of the Institute of Economic Research, Kyoto University (FY2011) and Hitotsubashi University (FY2011-2012). I am grateful to Josef Brada, Norio Horie, Katsuyuki Kubo, Satoshi Mizobata, Fumikazu Sugiura, and Riichi Tabata as well as participants at the study meeting at the Institute of Economic Research, Hitotsubashi University, Kunitachi, Tokyo, December 21, 2011, and the Conference on Economic and Financial System Development in the Pacific-Rim Region, Honolulu, Hawaii, May 16-19, 2012, for their helpful comments and suggestions. I would also like to thank Yoshisada Shida for his research assistance and Jim Treadway for his editorial assistance.
} 


\section{Introduction}

The countries of the world can be roughly classified into three groups in terms of the types of board systems and their selectability that are applied to joint-stock companies and limited liability companies with a certain level of capital and number of employees. The first group consists of those countries in which the law requires domestic firms to adopt a single-tier board system whereby a single corporate board carries out the dual functions of execution of the business and management control. Many countries, including the U.S., the U.K., and Japan, are in this category. The second group consists of those countries where the law requires domestic firms to adopt a multi-tier board system in which the dual functions reported above are shared by multiple boards through the division of tasks. It is well known that German company law requires the dual establishment of a board of directors and a supervisory board. In addition to Germany, countries in this group include the Netherlands, Denmark, Iceland, Estonia, Lithuania, and some other European countries as well as China, Taiwan, and some other Asian countries. Lastly, the third group consists of those countries in which corporate law allows domestic firms to arbitrarily select either a single-tier board system or a multi-tier board system under certain conditions. For example, French firms are allowed to choose either an Anglo-American-style single-tier board system or a German-style double-tier board system. Countries in this group include Italy, Finland, and Latvia. ${ }^{1}$

Russia, which has been adapting and upgrading its corporate law system to the market economy since the collapse of the Soviet Union, also belongs to this third group. As we will elaborate on later, in accordance with the Federal Law on Joint-Stock Companies (Law on JSCs), ${ }^{2}$ joint-stock companies that have been established in the territory of Russia may set up not only a board of directors (sovet direktorov in Russian) and a single executive body (edinolichnyi ispolnitelnyi organ), which refers to a top manager (CEO, President, or General Director), but also a

1 No reference is made in this paper to the relevant system of each country due to space limitations. For details, see country studies by Lausten (2002), Eriksson et al. (2003), van Ees et al. (2003), Gorton and Schmid (2004), Her and Mahajan (2005), Maury (2006), and Cho and Rui (2009) as well as international comparisons by Hopt and Leyens (2004), Jungmann (2006), Enriques and Volpin (2007), and Maitland-Walker (2008).

2 This refers to the Federal Law on Joint-Stock Companies dated December 26, 1995. This and the next sections were written with reference to laws or regulations that were in force during the period of the 2005 enterprise survey on which the empirical analysis in this paper is based. 
collective executive board (kollegialnyi ispolnitelnyi organ) as a third corporate board in charge of the execution of company management (Law on JSCs, Chapter 8). ${ }^{3}$ The establishment of a board of directors and that of a single executive body are enforced by law. In contrast, with regard to a collective executive board, the Law on JSCs does not contain any special requirements for either the establishment or the number of board members. These issues are entirely left to each firm's discretion. Furthermore, each firm with a collective executive board is allowed to freely regulate the scope of the board's authority, the ways of making resolutions, and other matters related to the board in the articles of incorporation to the extent that they do not conflict with the Law on JSCs and other laws (Shapkina, 2009). In this way, Russian firms can design their management control system with some degree of flexibility by utilizing a collective executive board.

There is no doubt that the types and nature of corporate board systems have a strong influence on the direction and performance of company management and corporate governance. Accordingly, the determinants of the selection of a board system warrant study from the viewpoint of both organizational economics and corporate finance. Nevertheless, to the best of our knowledge, in previous studies on relevant countries in which company law leaves the selection of a board system to a firm's discretion, there is no research on the firm-level determinants of board system choice, and, consequently, this issue remains unexplored.

In this paper, using a unique dataset of joint-stock companies based on a Japan-Russia joint enterprise survey conducted in 2005, we cast light on a collective executive board as a core element of the multi-tier board system of Russian firms and empirically examine the determinants of the choice and size of this unique corporate organ. The history of joint-stock companies in Russia is so short that a large number of firms retain investors and management executives as their founding members. Furthermore, domestic firms in this country are changing their company organizations, including management control systems, as a matter of common practice in order to respond to the dramatic environmental changes during the transition period to a market economy. These circumstances provide a great opportunity to examine the impact of ownership structure, lineup of management executives, nature of a firm's organization, and business activities on the formation of a collective executive board in Russian firms.

3 See Iwasaki (2007a) for more details on the legislative structure of Russian joint-stock companies. 
We reveal that about one third of surveyed firms have a collective executive board with a membership ranging widely from a minimum of 2 to a maximum of 23 persons. We also found that there are statistically significant gaps between different industrial sectors in terms of the probability of establishing a collective executive board and its membership size. Furthermore, the empirical analysis in this paper identified the factors that have a statistically significant and economically meaningful impact on firm-level decision making for the formation of a collective executive board, in line with our theoretical predictions. They include ownership by outside investors and management groups, presence of the federal government as a shareholder, affiliation with a business group through stock ownership, the relative authority and status of the top manager within his or her management group, the complexity of the company management, and differences in the form of incorporation. At the same time, our empirical evidence strongly suggests that Russian firms, in the pursuit of the internationalization of their business activities, might be avoiding the establishment of a collective executive board, which is diverse from the viewpoint of the international standard for corporate governance systems.

The reminder of this paper is organized as follows. Section 2 looks into the legal framework of executive bodies in Russian joint-stock companies. Section 3 describes the Japan-Russia joint enterprise survey, and, based on the findings, it provides an overview of the actual state of the executive bodies and identifies its structural features. Section 4 presents the testable hypotheses concerning the determinants of the choice and size of the collective executive board, and Section 5 empirically tests these hypotheses. Finally, Section 6 summarizes the major findings and concludes the paper.

\section{Legal Framework of Executive Bodies in Russian Joint-Stock Companies}

As reported in the Introduction, according to the Law on JSCs, Russian joint-stock companies are expected to establish two executive bodies, a single executive body and a collective executive board, each as a legal corporate organ to provide daily guidance for the company management (Law on JSCs, Art. 69 (1)). All joint-stock companies are required to establish the former, which is a one-person board consisting only of a top manager. Meanwhile, the establishment of the latter is at the discretion of each firm. ${ }^{4}$ In addition, Article 64 (1) of the Law on JSCs also stipulates that, if the number

4 According to the article 11.1 of the Federal Law on Banks and Banking Activities dated December 2, 1990, however, establishment of an executive board is not a voluntary affair 
of voting share owners is less than 50 shareholders, the company's general shareholders' meeting may also serve as the board of directors. In accordance with these provisions, Russian joint-stock companies have to select any one of the four types of corporate board systems illustrated in Figure 1. The status and authority of the top manager who serves as a single executive body are not very different from those of a typical CEO in the U.S. or the U.K. or those of a typical company president in Japan, except that Article 66 (2) of the Law on JSCs prohibits any top manager from concurrently serving as the chairman of the board of directors. Therefore, the firms that select Type IV or those including both a board of directors and a collective executive board can be said to have practically organized a multi-layer board system. The appointment and dismissal of executive board members during the term of their appointment is managed exclusively at the general shareholders' meeting (Law on JSCs, Art. 48 (1), Para. 8). However, as demonstrated in Figure 1, a general shareholders' meeting may delegate this authority to the board of directors if the relevant provision is set in the articles of incorporation (Law on JSCs, Art. 65 (1), Para. 9). ${ }^{5}$

The relationship between a company and its executive board members, who are appointed by either the general shareholders' meeting or the board of directors, has a significant influence on the management system and corporate governance of the company for two reasons.

First, the Law on JSCs prohibits more than 25\% of the board directorship from being represented by members of a collective executive board (Art. 66 (2)). In other words, executive board members, including the top manager, can never become a majority force in the board of directors under a board system of Type IV, as shown in Figure 1. This provision, combined with the prohibition on a single executive body

left to the discretion of a banking institution but a rule.

5 The rights and obligations of an appointed executive board member are stipulated in a contract to be agreed upon between the board member and the firm as his or her employer, and either the chairman of the board of directors or a person delegated by the board of directors shall sign the contract with the board member on behalf of the company. The labor law applies to relationships between firms and executive board members only to the extent that it does not conflict with the Law on JSCs (Art. 69 (3)). As reported by Iwasaki (2007a), however, there is a fierce debate over the rights of board members who are dismissed during the term of their appointment. The focal point in the controversy is whether contractual relationships between firms and executive board members are regulated on a civil-law basis or whether they are based on labor law (Mogilevskii, 2001; Rubeko, 2007; Kyrov, 2009). 
concurrently holding a post of the board chairman, strengthens the independence and supervisory functions of the board of directors in relation with top management (Mogilevskii, 2001; Iontsev, 2002). In addition, the Law on JSCs is intended to enhance the monitoring capabilities of other company officers and shareholders over the decision-making process in the senior management team by requiring a collective executive board to submit its minutes to the board of directors, the board of auditors, and the accounting auditor (Art. 70 (2)) and also by requiring the executive board to disclose its minutes to an individual shareholder or a group of shareholders with a proportional ownership of 25\% or more (Art. 91 (1)) (Rubeko, 2007). In this way, the formation of a collective executive board not only restricts the discretion of the management executives but also has the potential to direct the corporate governance system toward stronger supervisory capabilities over the executive officers on the part of company's monitoring institutions and shareholders.

Second, in every firm with a collective executive board, the single executive body is required to serve as the chairman of the collective executive board (Law on JSCs, Art. 69 (1)). The single executive body must preside over every meeting of the collective executive board, sign the minutes of each meeting, and act on behalf of the firm in accordance with the collective executive board's decisions as documented in these minutes (Art. 70 (2)). The Law on JSCs provides that the scope of the collective executive board's authority, together with the term of office for its board members, the convocation and procedural rules for the meetings, the quorum, voting methods, and the like, must be clearly stated in the articles of incorporation, but no further provisions are included in the law (Art. 69 (1) and Art. 70 (2)). ${ }^{6}$ Accordingly, with the aim of advocating the desirable role of corporate boards and corporate governance in Russia, the federal government promulgated the Corporate Governance Code (CG Code) in the form of a resolution of the Federal Commission for the Securities Market in April $2002^{7}$ and, thereby, recommended the establishment of a collective executive board and then encouraged the inclusion of a series of important management matters within

6 With regard to the quorum of a collective executive board meeting and the voting rights of the board members, the Law on JSCs prescribes only that the quorum for a collective executive board meeting must be at least half of the appointed board members and that the voting rights of the board members should never be delegated to other persons, including other board members (Art. 70 (2)).

7 The resolution of the Federal Commission for the Securities Market dated April 4, 2002 regarding the recommendation on the adoption of the Corporate Governance Code. 
the scope of this board's authority (Chapter 4, Section 1). ${ }^{8}$ According to the observations of a legal scholar, Russian firms practically provide the scope of responsibilities of each executive board in their articles of incorporation as well as in other internal documents and give fairly broad authority to their collective executive board (Rubeko, 2007). From this point of view, a Russian lawyer, who is well-versed in the legal affairs of joint-stock companies, has pointed out that a single executive body can share management responsibilities with key company executives if these senior managers participate in a collective executive board (Iontsev, 2002). In this way, the adoption of a collective executive board formally and practically contributes to the formulation of a collective management system in the firm.

In brief, the dual establishment of a single executive body and a collective executive board in a company suggests greater institutional enhancement of a company’s management control system and collective management responsibility than those found in other types of corporate board systems. This viewpoint is the key to identify the determinants of the formation of collective executive boards, which is the main priority of this paper. With this in mind, we will take a look at the actual state of executive boards in Russian firms in the next section.

\section{Formation of Executive Bodies in Russian Firms: A Statistical Overview}

In this section, we briefly describe the Japan-Russia joint enterprise survey as the basis for the empirical analysis in this paper; then, using the results, we examine the process of forming executive bodies in Russian firms and identify their structural features.

From February to June 2005, the Institute of Economic Research of Hitotsubashi University (Tokyo) and the Institute for Industrial and Market Studies of Higher School of Economics (Moscow) jointly conducted a large-scale enterprise survey in Russia. In the course of the survey, 859 members of top management from industrial and communications enterprises in 64 federal districts were interviewed by professional staff members of the Levada Center, the former USSR Public Opinion Poll Center of the Ministry of Labor, or its local branches. The target companies were

8 Concrete examples of such important matters listed in the said provision include (a) formulation of flagship documents including strategic action policies as well as financial and managerial plans, (b) approval of major transactions and loans, each of which amounts to the equivalent of at least $5 \%$ of company's total assets, (c) a series of issues related to the organization and management of subsidiaries, branches, and agents, and (d) approval of internal documents, including company working rules and job instructions. 
selected by the method of stratified sampling among firms with more than 100 workers. Of the 859 companies surveyed, valid responses were received from 822. Of these, 94.8\% were company presidents, CEOs, general directors, or vice presidents. The remaining respondents were board chairmen (1.6\%) or senior managers responsible for corporate governance affairs $(3.6 \%){ }^{9}$

All sample firms were joint-stock companies, and the average number of workers per company was 1,884 (median: 465). The total number of workers of these surveyed firms was $1,549,008$, which accounted for $10.3 \%$ of the total workforce in both the industrial and the communications sectors through 2004 according to official statistics (Rosstat, 2005). Furthermore, regarding the regional and sectoral composition of the surveyed firms, they formed a representative sample of Russian medium- and large-scale corporations, reflecting our research focus on the former state-owned enterprises transformed into joint-stock companies as a result of the mass-privatization policy in the early 1990s and their de novo private counterparts established in the transition period.

The responses from 818 surveyed firms, excluding four workers' joint-stock companies (people's enterprises), which were not expected to establish a collective executive board under corporate law, ${ }^{10}$ contain information about whether or not a collective executive board has been established, and, for companies with a collective executive board, information about the total number of board members. ${ }^{11}$

Next, based on the results obtained from our enterprise survey, we look at the practices of the formation of executive bodies in Russian companies.

9 The questionnaire used for the joint survey was carefully designed by the project members and experts of the Levada Center based on similar surveys conducted in the past, although it is impossible to completely avoid bias and moral hazard problems with respect to self-reporting.

${ }^{10}$ In addition, workers' joint-stock companies are very different from typical joint-stock companies in their establishment, capital management principles, allocation of authority among corporate organs, and decision making with regard to the appointment and remuneration of corporate officers (Iwasaki, 2007a).

11 In this survey, we also asked respondents about other aspects of their companies, including: (a) year and way of establishment; (b) form of incorporation; (c) ownership structure; (d) composition of top management teams and statutory company organs; (e) production, sales, investment, and fund procurement activities; (f) financial performance; (g) affiliation with a business group and basic attributes of the business group his/her company belongs to; (e) relationship with the state and business associations, and so forth. See Dolgopyatova and Iwasaki (2006) and Dolgopyatova et al. (2009, Appendix) for more details on the methods and results of the survey. 
As reported in the previous section, corporate board systems in Russian joint-stock companies can be classified into four types, depending on their structures with or without a board of directors and a collective executive board. Figure 2 shows the breakdown of 818 surveyed firms by board system and reveals that only 22 companies (2.7\%) of the 818 have general shareholders' meetings that directly supervise top management. In other words, despite the highly concentrated ownership structure and limited number of shareholders in a typical Russian firm, the system of a board of directors is widely adopted by joint-stock companies. At the same time, 280 firms, or $34.3 \%$ of all surveyed firms, organize either a Type II or a Type IV board system, both of which include a collective executive board. These facts suggest that many Russian firms utilize a multi-tier board system in which the collective executive board shares execution of the business with the board of directors and a single executive body irrespectively of the obscure and insufficient provisions of the Law on JSCs.

Of the 280 companies with a collective executive board, 262 disclosed the total number of their board members upon our request. According to these responses, a collective executive board consists of 7.3 persons on average (standard deviation: 3.9; median: 7). As shown in Figure 3, 53 firms (20.2\%) form a collective executive board of 5 persons. This group is followed by 37 firms (14.1\%) with 3 members, 33 firms (12.6\%) with 7 members, and 25 firms (9.5\%) with a 9-member collective executive board. At the same time, 60 firms have a relatively large collective executive board with at least 10 members, accounting for only $22.9 \%$ of the 262 companies. These findings indicate that a collective executive board consists of a limited number of officers even in large and medium-sized companies.

The surveyed firms belong to either 8 industrial sectors or the communications sector. Table 1 shows an industry-to-industry comparison among the 9 industries in terms of the proportion of companies with a collective executive board and the total number of board members. As revealed in this table, the proportion of companies with a collective executive board in relation to the total number of industrial companies is $31.9 \%$, while the corresponding proportion reaches as high as $60.0 \%$ for communications companies. Moreover, the proportion among the 8 industrial sectors ranges from $47.0 \%$ in the fuel and energy industry to $21.7 \%$ in the food industry, showing remarkable sector-to-sector disparities. In general, firms in heavy industry tend to be more aggressive in establishing a collective executive board than those in other types of industry. In terms of the size of board membership, although the disparities are not as clear as in the proportion of companies with a collective executive 
board, certain differences are also evident among the 9 industries. In fact, the $t$ test on the equality of means and the multiple comparison in terms of the board size prove that there are statistically significant differences not only between the industrial and communications sectors but also among the 9 industries, as is the case with results of the chi-square test for the homogeneity of proportions and the chi-square test of independence in terms of the proportion of companies with a collective executive board.

Overall, our survey results demonstrate that a large number of Russian firms have adopted a collective executive board and its membership size varies quite widely. It is also confirmed that there are statistically significant gaps among different industries in terms of the probability of establishing a collective executive board as well as the total number of board members. Based on these findings, we will theoretically consider and empirically analyze the determinants of the choice and size of the collective executive board in the following two sections.

\section{Hypotheses Development}

In this section, on the basis of arguments and empirical evidence in preceding research on organizational economics, corporate finance, and management organization as well as those of social network research, we present testable hypotheses concerning the possible determinants of the formation of a collective executive board with the structural features reported in the previous section. In light of the legal framework governing executive bodies described in Section 2 and the political and economic circumstances in transition Russia, we pay attention to the following seven factors that could significantly affect decision making by Russian firms regarding the choice and size of a collective executive board: (1) ownership by outside investors and management executives; (2) presence of the federal government as a shareholder; (3) affiliation with a business group through stock ownership; (4) the relative authority and status of a top manager within his or her management group; (5) the complexity of the company management; (6) the form of incorporation; and (7) organizational continuity from the Socialist period.

First, organizational economics and corporate finance research suggest that shareholders face agency problems caused by the separation of ownership from management and, therefore, need an effective management control system to restrict and prevent management executives from deviating from the objective of maximizing 
corporate value and/or self-seeking opportunism (Williamson, 1996; Jensen, 2000). As discussed in Section 2, a company with a collective executive board has the potential to strengthen the independence of a board of directors from the management team, subject to the restrictive provisions of the Law on JSCs, which limits board directorships from being represented by members of the collective executive board. Moreover, the obligation of a collective executive board to submit its minutes to the board of directors, the board of auditors, and the relevant accounting auditor as well as the right of an individual shareholder and a group of shareholders with $25 \%$ or more ownership to inspect these minutes will contribute to making the managerial decision-making process and the scope of responsibilities concerning important matters of company management more transparent. Beyond differences in country and period, a large number of previous studies have repeatedly verified that the presence of outsider shareholders tends to build an effective corporate governance system to discipline top management (Li, 1994; Gillan and Starks, 2003). From the same viewpoint, we expect that, in Russia, outside investors will demand that their companies establish a collective executive board and that as many senior managers as possible join the board. On the other hand, as observations by Filatotchev et al. (1999) on the managerial entrenchment in Russia suggest, if Russian managers are quite averse to stronger business supervision and limits on management discretion, they will execute their voting rights in order to prevent such a demand from the shareholders. Accordingly, we propose the following hypothesis:

$\mathrm{H}_{1}$ : Ownership by outside investors is positively correlated with the probability of establishing a collective executive board and its membership size, while ownership by management executives restrains both the choice and size of a collective executive board.

A second factor for a possible determinant of the formation of the collective executive board is the presence of the federal government as a shareholder. Even after the large-scale enterprise privatization during the 1990s, the Russian government still holds a large volume of shares in specific enterprises and has a strong voice in these state-owned enterprises (Iwasaki, 2007c). As reported in Section 2, the federal government promulgated the CG Code in 2002 and called on domestic firms to comply with this document. However, since the CG code is a nonbinding statement of recommendation, the federal government has a motivation to take concrete action to promote the code on its own initiative. Hence, it is likely that the federal government 
attempts to demand that state-owned enterprises follow the state recommendations included in the CG Code, using the government's capability to exercise its influence directly in these firms. In fact, empirical evidence reported by Frye and Iwasaki (2011), who examine the behavioral patterns of board directors sent from the federal government to state-owned enterprises, clearly indicates such a tendency. The encouragement for establishing a collective executive board is no exception. At the same time, the federal government also needs to ensure managerial discipline in state-owned enterprises to secure stable fiscal revenues while fulfilling political accountability to the public (Yakovlev, 2009). Therefore, just like private investors, the federal government will also demand that management executives participate extensively in a collective executive board. Consequently, we assume the following:

$\mathrm{H}_{2}$ : Presence of the federal government as a shareholder enhances the establishment of a collective executive board and expands its membership size.

A third factor is affiliation to a business group through stock ownership. Dynamic business integration among domestic firms is one of the remarkable characteristics of the Russian transition economy, in which various business groups have emerged beyond industrial and regional differences (Avdasheva, 2005; Radygin, 2006). In fact, our survey results indicate that 323 (39.3\%) of the 822 surveyed firms belong to their respective business groups through shareholdings. These business groups may urge their member companies to establish collective executive boards not only on the basis of a motivation similar to that of outside investors, as discussed above, but also due to the need to build a close network within the company group. As a series of social network studies and management organization research suggests, this is because that well-structured and disciplined activities among member firms through company networks are essential for successfully guiding the management strategy of the entire group (O’Toole, 1997; Barnes and Liao, 2012). Empirical evidence from this research field also indicates that the performance of collective action largely depends on the frequency and quality of information flow among the actors (Granovetter, 1973; Johnson and Wechsler, 1990; Schilling and Phelps, 2007). A collective executive board, which is assumed to exchange business information and discuss management issues more frequently than corresponding board of directors, can serve as a venue for close and accurate communication among group companies. ${ }^{12}$ The general understanding is

12 In fact, the CG Code recommends that boards of directors hold at least one meeting every 
that a collective executive board consists of a firm's senior managers but accepting an outsider board member(s) is not necessarily prohibited by the Russian corporate law. Rather, there is ample room for mutual exchanges between executive board members among group companies. In fact, the results of our follow-up survey found that some of the surveyed firms are indeed practicing such personnel exchanges. ${ }^{13}$ Thus, it is highly probable that each member company within a business group has established its own collective executive board, through which personnel exchanges are conducted at the vice president level or at the level of the heads of divisions or departments. In addition, the acceptance of an outside board member from another group company is considered to require expansion of the collective executive board membership to secure this new seat. Based on these arguments, we hypothesize:

$\mathrm{H}_{3}$ : The probability of establishing a collective executive board and its membership size are higher in group companies than in independent firms.

The relative authority and status of a top manager may also influence his or her company's strategic decision making, including business executive systems (Adams et al., 2005; Xuan, 2009). As argued in Section 2, the establishment of a collective executive board suggests that senior managers, including the top manager, have selected a system in which they collectively assume certain responsibility for company management. As a background factor for the adoption of the collective management system, we can point to the condition under which the authority and status of the top managers are relatively low within a group of management executives due to their line of promotion and work experience. In other words, each internally promoted top manager, who tends to need direct or indirect support from his or her colleagues on the occasion of taking the top managerial position, and a top manager with only limited work experience are considered to have a relatively greater reliance on other management executives (Weisbach, 1988; Linck et al., 2008). Meanwhile, when other company officers, such as a vice president or a head of department or division, have a strong voice, the top manager may be lured into transferring his or her authority and responsibilities to these executives. Ultimately, such a power transfer is likely to result

six weeks (Chapter 3, Section 4, Article 4.2.1) while calling on collective executive boards to hold at least one meeting every week (Chapter 4, Section 4, Article 4.1.1).

13 The follow-up survey was conducted using the SPARK commercial enterprise database (http://www.spark.interfax.ru). The kind assistance from Svetlana Avdasheva and Tatiana Dolgopyatova in the implementation of the survey is highly appreciated. 
in the formulation of a collective management system in the form of the adoption of a collective executive board (Hackman and Dunphy, 1990; Yukl and Fu, 1999). We therefore make the following prediction:

$\mathrm{H}_{4}$ : The internal promotion as well as short tenure of a top manager is positively correlated with the probability of establishing a collective executive board and its membership size in his or her company.

The complexity of company management is a fifth factor that may affect the formation of a collective executive board. Top management has become increasingly complex in the wake of the expansion of firm organizations, the diversification and internationalization of business activities, the intensively evolving $R \& D$ and innovation activities, and fund procurement from the capital market or financial institutions. To cope effectively with such complexity, more sources of information and competent judgment are required (Ashmos et al., 2000). If a management team is composed of diverse members in terms of age, educational background, and expertise, its composition will satisfy these needs and, thereby, support the top manager and enhance the problem-solving abilities of the firm (Bantel and Jackson, 1989; Haleblian and Finkelstein, 1993). Therefore, if a firm faces a more complex management environment, a stronger incentive will be created in this organization to officially develop a collective management system. This argument leads us to the following hypothesis:

$\mathrm{H}_{5}$ : The complexity of company management increases the probability of establishing a collective executive board and expands its membership size.

A sixth factor to be considered is the form of incorporation. In accordance with Article 97 of the Civil Code ${ }^{14}$ and Article 7 of the Law on JSCs, an individual who intends to set up a joint-stock company in Russia must choose as the legal form for its incorporation either an open company, whose shares can be freely traded, or a closed company, whose shares are allowed to be allocated and/or transferred only among the promoters and other designated investors. ${ }^{15}$ As previous studies on the relationship between corporate liquidity and takeover risk imply (Garvey and Hanka, 1999; Yun,

${ }^{14}$ Part I of the Civil Code dated November 30, 1994.

15 Between these two forms of incorporation, certain differences are stipulated in terms of the minimum capital requirement, the number of shareholders, and the obligation to disclose information (Iwasaki, 2007a, 2007b). 
2009; Madura et al., 2012), an open company, whose shares can be transferred to any third party without any difficulties, has a much higher probability of calling in a strategic investor as one of its shareholders than a closed company, which can effectively limit share transfers to any outsider. These shareholders not only have a strong tendency to show an aggressive stance toward management responsibility but also often emerge as the promoters of hostile takeovers or shareholder lawsuits in Russia and cause conflicts or serious management problems (Demidova, 2007; Radygin, 2009). The presence of this type of shareholder is a major factor in strengthening the collective solidarity of senior managers. Accordingly, an open company has a higher probability of selecting a collective management system than a closed company, if other conditions are equal. Thus, we expect:

$\mathrm{H}_{6}$ : The selection of an open joint-stock company as the form of incorporation is positively associated with the probability of establishing a collective executive board and its membership size.

We regard organizational continuity from the Socialist period as the seventh factor determining the formation of the collective executive board. In the Soviet era, most state-owned enterprises had incorporated a directorate (pravlenie or direktsiya), which is the institutional predecessor of the collective executive board, to form a firm-level executive organ supervised by a general director. Under current laws, the name "directorate" has been officially adopted as an alternative title for a collective executive board. This name as a legacy from the past carries on the history of the "directorate" defined as one of the forms of legal corporate boards according to the government ordinances of the Soviet Union and the Russian Federation, which regulated the board systems in state-owned enterprises and those in privatized firms for a long time from the Socialist period to 1994, when the newly born Russia enacted the Civil Code. ${ }^{16}$ If Russia strongly retains institutional inertia and path-dependency from

16 The name "directorate" appeared in the context of a core business executive board in industrial enterprises as early as June 29, 1927, when the Resolution of the Central Executive Committee USSR and the Council of People's Commissars "On the Approval of the Provisions of State-Owned Industrial Trusts" were promulgated. Later on, it was also inherited through a series of government documents as follows: the Resolution of the Cabinet of Ministers of the USSR "On the Approval of the Provisions of Socialist State-Owned Production Enterprise” dated October 4, 1965; the Resolution of the Cabinet of Ministers of the USSR "On the Approval of the Provisions of Joint-Stock Companies and Limited Liability Companies and the Provisions of Securities" dated July 19, 1990; the Resolution of the Cabinet of Ministers of the Russian Socialist Federation "On the 
the Socialist period, both former state-owned (ex-municipal) privatized companies, which inherited business assets from socialist enterprises, and companies spun off from state-owned (municipal) companies or former state-owned (ex-municipal) privatized companies are considered to have a relatively higher probability of establishing or maintaining a collective executive board that institutionally inherits a directorate than firms that were newly established after the collapse of the Soviet Union. Accordingly, we hypothesize:

$\mathrm{H}_{7}$ : Former state-owned (ex-municipal) privatized companies and companies spun off from state-owned (municipal) companies or former state-owned (ex-municipal) privatized companies have a higher probability of establishing a collective executive board than newly established firms during the transition period.

Table 2 summarizes the above theoretical considerations. In the next section, we empirically examine these testable hypotheses.

\section{Empirical Analysis}

In this section, we estimate regression models that take the probability of establishing a collective executive board and the size of the board membership as dependent variables. The former can be written as a discrete choice model with a dummy variable for firms with a collective executive board $\left(y_{c}\right)$ on the left-hand side as

$$
\operatorname{Prob}\left(y_{c}=1\right)=\mu_{c}+\sum_{i=1}^{n} \beta_{i} x_{i}+\varepsilon_{c}
$$

where $\mu$ is a constant term, $x$ is a dependent variable, $\beta$ is a parameter to be estimated, and $\varepsilon$ is an error term. We estimate Equation (1) using a probit model.

The size of the board membership is observable only in companies having a collective executive board. Therefore, the regression model taking the board size $\left(y_{s}\right)$ as the dependent variable would be in the form of:

Approval of the Provisions of Joint-Stock Companies” dated December 25, 1990; and the Presidential Decree of the Russian Federation "On Organizational Measures to Transform State-Owned Enterprises and Voluntary Associations of State-Owned Enterprise into Joint-Stock Companies” dated July 1, 1992. 


$$
f\left(y_{s}\right)= \begin{cases}0 & \text { if } y_{c}=0 \\ \mu_{s}+\sum_{i=1}^{n} \beta_{i} x_{i}+\varepsilon_{s} & \text { if } y_{c}=1\end{cases}
$$

It is well known that an OLS estimation of such a model may produce inconsistent estimates of $\beta$ due to sample selection bias (Greene, 2011). We, hence, estimate Equation (2) using a maximum likelihood sample selection model. ${ }^{17}$

Based on the above model specification, subsection 5.1 selects variables to be used in the regression analysis. Subsection 5.2 reports the estimation results. Subsection 5.3 checks their statistical robustness.

\subsection{Variable Selection}

On the left-hand side of the regression models to be estimated, we introduce two types of dependent variables: one is a dummy variable that assigns a value of 1 to companies with a collective executive board (COLEXE); and another is a board size variable that is computed by adding 1 to the total number of collective executive board members and then converting the sum to a logarithmic scale (COLSIZ).

On the right-hand side of the regression models, the following 32 variables are introduced: The impact of ownership by outside investors and management executives as well as the presence of the federal government as a shareholder on the formation of a collective executive board is examined by the combined ownership share of non-managerial shareholders, excluding domestic individuals (OWNOUT), ${ }^{18}$ a large management shareholder dummy that assigns a value of 1 if a company has a specific manager or a specific managerial group as its large shareholder (MANSHA), and the ownership share of the federal government (OWNFED). Besides these three ownership variables, in order to take account of the possibility that the difference between the state and private investment, the difference between the federal government and regional and local governments, and the difference among various types of private

17 When the independent variables used in the first stage of estimation materially overlap with those used in the second stage, the conventional Heckman two-step estimation method, which combines the probit and the OLS models, tends to cause a multicollinearity problem due to the use of the inverse Mill's ratio. For this reason, the maximum likelihood method is employed to estimate our sample selection models.

${ }^{18}$ We completely exclude the ownership share of domestic individual shareholders from OWNOUT in order to eliminate the ownership effects from those of the management executives' family members, relatives, or friends as well as those of employees, all of whom are formally categorized as outside shareholders. 
investors may have a different impact on invested firms, we also use the ownership share of the following entities: whole state (OWNSTA); whole private investors (OWNPRI); regional and local governments (OWNREG); commercial banks $(O W N B A N)$; investment funds and other financial institutions (OWNFIN); non-financial corporate shareholders (OWNCOR); and foreign investors (OWNFOR).

In order to examine how affiliation with a business group through stock ownership affects the choice and size of a collective executive board, we use a group firm dummy that assigns a value of 1 to firms that belong to a holding company group or another business group by owning stocks (GROFIR). We also use a core group firm dummy $(G R O C O R)$ and an affiliate firm dummy (GROAFF) to identify the possible asymmetrical effects of business integration on the formation of a collective executive board due to differences among member firms in their position within the group.

To assess the degree of dependence of a top manager on his or her management group, two types of dummy variables are used: one is an insider CEO dummy that assigns a value of 1 to companies in which the incumbent top manager has been internally promoted (INSCEO), and the other is a new CEO dummy that takes 1 for those firms with a top manager appointed in or after 2001 (NEWCEO).

Furthermore, as a proxy of company size, we use a natural logarithm of the average annual number of employees (COMSIZ). Meanwhile, as variables that reflect the extent of business diversification, the degree of business internationalization, and the intensity of R\&D and innovation activities, we utilize the number of business lines of the company in accordance with the 2-digit industrial classifications in the Russian All-Union Classifier of the National Economy Branches (BUSLIN), the share of exports in total sales (EXPSHA), and a dummy variable that assigns a value of 1 if a company successfully developed new products or started innovation businesses in the period from 2001 to 2004 (NEWPRO). The intensity of fund raising from the capital market is represented by a dummy variable that takes 1 for those companies that have issued bonds or shares in overseas or domestic stock exchanges (MARFIN), while the intensity of fund procurement from financial institutions is represented by an ordinal variable for the length of the lending period of bank credits borrowed by surveyed firms during the period from 2001 to 2004 (BANCRE). These six variables are assumed to have values that are in proportion to the complexity of company management.

The effect of a difference in the form of incorporation on the formation of a collective executive board is estimated using a dummy variable that captures open joint-stock companies by 1 (OPECOM), while the impact of organizational continuity 
from the Socialist period is examined by two dummy variables which indicate whether the company is a former state-owned (ex-municipal) privatized company (PRICOM) or a company spun off from a state-owned (municipal) company or a former state-owned (ex-municipal) privatized company (SPIOFF).

In addition to these 24 variables, we also employ eight industry dummies with the communications sector as a default category to control the fixed effects in each industry that are unobservable for econometricians. ${ }^{19}$

Table 3 provides more detailed content and definitions of the above 24 independent variables as well as their descriptive statistics. This table also presents the results of the univariate comparative analysis between two sub-sample groups divided in terms of the adoption of a collective executive board. The correlation coefficients between each variable and the total number of collective executive board members are also reported. As the table shows, the average ownership share of every type of outsider investor in firms with a collective executive board exceeds the corresponding share in firms without it, except for only $O W N R E G$, and, with regard to seven out of these nine ownership variables, including $O W N F E D$, there are statistically significant differences between the two sub-sample groups at the $10 \%$ or less level according to either the $t$ test on the equality of means or the Wilcoxon rank-sum test. In addition, six out of the nine variables are positively correlated with the number of collective executive board members with statistical significance at the $5 \%$ level or below. In terms of the proportion of companies that have a manager or a management group as its large shareholder, the difference between firms with a collective executive board and those without one is not statistically significant. However, MANSHA shows a significant and negative correlation coefficient with the board size, in line with our prediction. Moreover, according to the results of the comparative analysis using GROFIR, which captures companies affiliated to a business group, 50.0\% of the firms with a collective executive board are group firms, while only $33.6 \%$ of the firms without a board belong to a business group. This difference is also statistically significant at the $1 \%$ level according to the chi-square test for the homogeneity of proportions. The univariate analysis based on GROAFF also shows a similar result.

Firms with a collective executive board also exceed those without one in terms of

19 The mean of the absolute value (standard deviation) and the maximum value of the correlation coefficient of the independent variables that are simultaneously estimated in the regression analysis are $0.090(0.090)$ and 0.543 , respectively. Thus, every combination falls well below the threshold of 0.700 for possible multicollinearity. 
company size, number of business lines, intensity of R\&D and innovation activities, rate of issuing shares and/or bonds in the capital market, and intensity of the use of bank credits. Moreover, the three variables of COMSIZ, BUSLIN, and MARFIN are significantly and positively correlated with the board size. In addition, the comparative analysis using OPECOM reveals that a relatively higher percentage of firms with a collective executive board than without one select an open company as their form of incorporation. Meanwhile, the results of the univariate analysis based on the four variables that capture the attributes of top managers and organizational continuity from the Socialist period (i.e., INSCEO, NEWCEO, PRICOM, and SPIOFF) show no statistically significant difference between companies with and without a collective executive board.

The above univariate analysis fully or partly supports Hypotheses $\mathrm{H}_{1}, \mathrm{H}_{2}, \mathrm{H}_{3}, \mathrm{H}_{5}$, and $\mathrm{H}_{6}$. In the next subsection, we will test whether similar results will also be reconfirmed in multivariate regression settings that simultaneously control the independent variables.

\subsection{Estimation Results}

Table 4 presents the probit estimation results of Equation (1) that takes the probability of establishing a collective executive board (COLEXE) as the dependent variable. To compute standard errors, we used White's heteroskedasticity-consistent estimator. As the table shows, many variables for ownership by outsider investors do not have a statistically significant estimate, contrary to the results from the univariate analysis reported in Table 3. What is more, against our prediction, OWNFOR, which reflects the ownership share of foreign investors, shows a negative estimate with statistical significance at the $10 \%$ level. On the other hand, the coefficient of $O W N F E D$ has a positive sign, and its statistical significance reaches the $5 \%$ level, suggesting that, in a sharp contrast to politically indifferent regional and local governments, the federal government effectively exercises its voting rights to implement its own recommendations described in the CG Code concerning the desirable roles of executive bodies.

The positive and significant estimate of GROFIR indicates a more active attitude of group firms than independent firms towards the adoption of a collective executive board. In addition, GROAFF shows higher statistical significance than GROCOR, indicating the possibility that a collective executive board is utilized as a venue for management supervision over affiliated firms by the core group firm and/or for 
exchanges of board members among affiliated firms.

Among two dummy variables that capture the attributes of top managers, INSCEO is positively estimated with statistical significance at the $10 \%$ level. As many management researchers pointed out, Russia is characterized by a stronger collectivism-oriented organizational culture than not only Western nations but also major Asian countries, including Japan (Abe and Iwasaki, 2010). In a country with such a culture, a top manager who has been internally promoted is considered to have extremely strong connections and a sense of solidarity with the surrounding senior managers, and this environment is likely to enhance the in-house willingness to adopt a collective management system in the form of the combination of a single executive body and a collective executive board. The positive and significant estimate of INSCEO suggests a strong tendency of Russian firms to exhibit this collectivism orientation.

Furthermore, it is verified by the positive and significant estimates of three proxy variables, namely, COMSIZ, NEWPRO, and BANCRE, that, in general, the complexity of company management also works as a promoting factor of the adoption of a collective executive board. In other words, in the case of Russia, companies that have a large organization and are highly active in both $R \& D$ and innovation activities and fund procurement from commercial banks have a higher probability of establishing a collective executive board as a means of institutionally formalizing a collective management system.

In contrast, EXPSHA, which reflects the dependence of a company's business activities on foreign markets, has a negative and significant coefficient, as is the case with $O W N F O R$. This result needs to be interpreted from a new angle to explain the causality between business internationalization and management control systems in Russia. As advocated by Cohen and Boyd (2000) and Braendle and Noll (2006), the globalization wave throughout the international community forces companies, especially those active in overseas fund procurement and foreign business development, to adopt an internationally standardized corporate governance system. This trend is also noticeable in Russia, where integration with the world economy is advancing. In fact, Russian firms, particularly large and medium-sized companies, have been willingly adopting the Anglo-American style of management (Dolgopyatova, 2009). In this context, it has to be said that the collective executive board, as an institutional holdover from the Soviet era, is a diverse corporate board from an international point of view. The negative correlation of the choice of a collective executive board with 
both the foreign ownership share and the export share in total sales shown in Table 4 can be considered as strong evidence that the shareholders and/or management executives in Russian firms that have achieved a certain level of internationalization are becoming more passive or rather negative towards the formation of a collective executive board.

The estimate of OPECOM has a positive sign with statistical significance at the $1 \%$ level, suggesting that the difference in the form of incorporation between an open and a closed joint-stock company greatly affects decision making in Russian firms with regard to the choice of a collective executive board, in line with our expectations. Meanwhile, the estimation results of both PRICOM and SPIOFF are insignificant, indicating that the hypothesis concerning the causal relationship between the inheritance of business assets from socialist enterprises and the formation of a collective executive board is not valid for understanding the Russian reality.

Table 5 shows the estimation results of Equation (2) using the sample selection model with the size of the collective executive board (COLSIZ) as the dependent variable. Here again, White's estimator is used to compute the robust standard errors.

Table 5 shows that an extremely limited number of independent variables are significantly related to the board size. In line with our prediction, the coefficient of the ownership share of private investors (OWNPRI) shows a significant and positive sign. Closely looking at the relevant results by the type of private investor, however, only the ownership share of non-financial corporate shareholders (OWNCOR) has a statistically significant impact. On the other hand, as is the case with the estimation results of the choice of the collective executive board, OWNFED again shows a significant and positive estimate, suggesting the strong policy involvement of the federal government in the formation of executive bodies in state-owned enterprises. In contrast, $O W N R E G$ is again estimated to be insignificant, reconfirming that regional and local governments maintain a neutral attitude toward the corporate governance system of municipal companies.

MANSHA is negatively correlated with COLSIZ with statistical significance at the $10 \%$ level, suggesting that a large managerial shareholding serves to restrict the organizational expansion of the relevant collective executive board. This and the corresponding result reported in Table 4 indicate that management executives do not strongly resist the establishment of a collective executive board itself when there is an internal need to formalize a collective management system; rather, they stubbornly try to avoid any situation in which the membership of the collective executive board is set 
up too broadly and, thereby, the voice of senior managers on the board of directors might be significantly restricted by the limitations on the board directorship being represented by the collective executive board members, as stipulated in the Law on JSCs. ${ }^{20}$ If these regulations are aimed at strengthening the supervisory framework governing management executives, the legal design needs to be reconsidered.

Among the rest of the independent variables, only company size has a considerable impact on the size of the collective executive board. Indeed, the estimate of COMSIZ has a positive sign, and its statistical significance is at the $1 \%$ level. The other factors, including affiliation to a business group, diversification and internationalization of the business activities, intensity of $R \& D$ and innovation activities, external fund raising activities, form of incorporation, and organizational continuity from socialist enterprises, have no significant correlation with board size. Based on these estimation results, we conjecture that, in Russia, the scope of the senior managers qualified to be collective executive board members depends greatly on the scale of the company and is not significantly affected by the company's business activities and its history.

\subsection{Robustness Check}

To check the overall robustness of the empirical results reported in Tables 4 and 5, we conducted a supplemental estimation in which various sample restrictions were placed on the regression models and confirmed that these sample restrictions do not cause any major changes in the estimation results. More specifically, supplementary regressions were performed with the following nine settings: (1) limiting the samples to industrial enterprises; (2) excluding companies operating in the fuel/energy, metallurgy, and communications sectors, which are subject to unique government regulations regarding firm organization and business activities; (3) limiting the samples to those with a company size within the mean \pm 1 standard deviation to exclude very large enterprises from the observations; (4) limiting the samples to companies that have not issued securities; (5) limiting the samples to non-group-affiliated firms (i.e., independent firms); (6) excluding companies that do not have a board of directors from the observations; (7) dividing the samples into open and closed joint-stock companies; (8)

20 Using the same dataset in this paper, Iwasaki (2008) analyzed the composition of the board of directors and found that the establishment of a collective executive board has no statistically significant impact on the outside directorship. This result is considered to be attributable to the behavior of senior managers, who avoid placing restrictive regulations on the directorship being represented by collective executive board members. 
excluding from the observations firms that underwent a significant change in the ownership structure a few years before the survey, taking into account a possible estimation bias caused by the simultaneous relationship between ownership structure and board system; (9) excluding from the observations firms that underwent significant changes in their top managers and management executives a few years before the survey, considering a possible estimation bias caused by the simultaneity between the lineup of management executives and the board system.

As reported above, to examine the determinants of the size of the collective executive board, we estimated the sample selection models using the maximum likelihood method to deal with possible sample selection bias. As is shown in Table 5, however, the Wald test of the independence of equations cannot reject the null hypothesis $(\rho=0)$ for all the models. Moreover, the conventional Heckman two-step estimation has also shown that the inverse Mill's ratio is not statistically significant. In this regard, by means of alternative estimation methods, we have limited the observations to firms with a collective executive board and then estimated an OLS model that takes COLSIZ as the dependent variable and a Poisson model in which the total number of collective executive board members is introduced into the left-hand side of the regression equation. As a result, we confirmed that there are no noteworthy differences in the estimation results of these two alternative models from those reported in Table 5 in terms of the sign and statistical significance of the regression coefficients.

Therefore, we can confidently say that the estimation results reported in this section are fairly robust across the various specifications.

\section{Conclusion}

The collective executive board constitutes a core element of the multi-tier board system of Russian companies. In this paper, we empirically examined the determinants of the choice and size of the collective executive board using the results of a nation-wide enterprise survey conducted in 2005. As pointed out in the Introduction, little is known about firm-level determinants of board system choice. This paper is a first step into that untouched research subject and, hence, brings a contribution to financial and corporate governance literature.

Our survey results revealed that about one third of the surveyed firms set up both a single executive body and a collective executive board, although the establishment of 
the latter is left to the full discretion of each company by law. We also found that the size of the collective executive board ranges widely from a minimum of 2 persons to a maximum of 23. In addition, the survey results have shown that there are statistically significant gaps between different industrial sectors in terms of both the probability of establishing a collective executive board and its membership size.

The empirical results reported in the previous section fully or partly support our hypotheses, except for Hypothesis $\mathrm{H}_{7}$, regarding organizational continuity from the Socialist period. In other words, the probability of establishing a collective executive board is higher in the following settings than otherwise: when the federal government is involved as a shareholder; when the firm belongs to a specific business group through stock ownership; when the top manager has been internally promoted; when the company size is relatively large; when the firm is highly motivated in R\&D and innovation activities; when the company actively uses bank credits; and when the company selects an open joint-stock company as its form of incorporation. It has also been revealed that the size of the collective executive board is positively correlated with the ownership share of the federal government and that of non-financial corporate shareholders as well as company size, while the board size tends to be restricted in firms in which a management executive(s) holds a large number of shares.

As presented in Section 2, the establishment of a collective executive board and the consequent construction of a multi-tier board system might strengthen the management control functions and the collective management responsibility. However, our empirical results strongly suggest that, while the need for management executives to establish a collective management system is a major driving force in the adoption of a collective executive board in their firm, outside investors are generally indifferent toward the establishment of a collective executive board as a means to strengthening the monitoring and control functions over top management. The federal government, which is enthusiastic about promoting the CG Code, is only an exception. In order for collective executive boards to fully function as a tool for managerial discipline, the legal design needs to be further refined, and the institutional purposes of the collective executive board should be more publicized among investors and shareholders.

Another interesting finding reported in this paper concerns the growing globalization pressure and how it affects the management control system of Russian firms. Specifically, we found that Russian companies which pursue the internationalization of business activities through the acceptance of foreign investment and/or export of their products have a firm tendency to avoid the establishment of a 
collective executive board. The dynamism of international standardization and the convergence of corporate governance systems led by the developed economies and leading multinational enterprises have intensively involved Russian firms with an eye toward overseas markets and have been substantially affecting their decision making (Hopt and Leyens, 2004; Dolgopyatova, 2009). As long as this trend continues, the context of globalization should not be disregarded even in research of Russian corporations.

\section{References}

Abe, Naohito and Ichiro Iwasaki (2010), Organisational culture and corporate governance in Russia: A study on managerial turnover, Post-Communist Economies, 22(4), 449-470.

Adams, Renée B., Heitor Almeida and Daniel Ferreira (2005), Powerful CEOs and their impact on corporate performance, Review of Financial Studies, 18(4), 1403-1432.

Ashmos, Donde P., Dennis Duchon and Reuben R. McDaniel, Jr, (2000), Organizational responses to complexity: The effect on organizational performance, Journal of Organizational Change Management, 13(6), 577-595.

Avdasheva, Svetlana (2005), Business groups in Russian industries, In: Oleinik, Anton N. (ed.), The institutional economics of Russia's transformation, Ashgate: Aldershot, 290-308.

Bantel, Karen A. and Susan E. Jackson (1989), Top management and innovations in banking: Does the composition of the top team make a difference? Strategic Management Journal, 10(S1), 107-124.

Barnes, Jane and Ying Liao (2012), The effect of individual, network, and collaborative competencies on the supply chain management system, International Journal of Production Economics, 140(2), 888-899.

Braendle, Udo C. and Juergen Noll (2006), On the convergence of national corporate governance systems, Journal of Interdisciplinary Economics, 17(1-2), 57-81.

Cho, Stella and Oliver M. Rui (2009), Exploring the effects of China's two-tier board system and ownership structure on firm performance and earnings informativeness, Asia-Pacific Journal of Accounting and Economics, 16(1), 95-118.

Cohen, Stephen S. and Gavin Boyd (eds.) (2000), Corporate governance and globalization: Long range planning issues, E. Elgar: Cheltenham.

Demidova, E. (2007), Vrazhebnyie pogloshcheniya i zashchita ot hikh v usloviyakh korporativnogo rynka Rossii, Voprosy Ekonomiki, (10), 70-84. (in Russian)

Dolgopyatova, T. (2009), Korporativnoe upravlenie v rossiiskikh kompaniyakh: rol' grobalizatsii i krizisa, Voprosy Ekonomiki, (6), 83-96. (in Russian)

Dolgopyatova, Tatiana G. and Ichiro Iwasaki (2006), Exploring Russian corporations: Interim report on the Japan-Russia joint research project on corporate governance and integration 
processes in the Russian economy, IER discussion paper series No. B35, Institute of Economic Research, Hitotsubashi University, Tokyo.

Dolgopyatova, Tatiana, Ichiro Iwasaki and Andrei A. Yakovlev (eds.) (2009), Organization and development of Russian business: A firm-level analysis, Palgrave Macmillan: Basingstoke.

Enriques, Luca and Paolo Volpin (2007), Corporate governance reforms in continental Europe, Journal of Economic Perspectives, 21(1), 117-140.

Eriksson, Tor, Erik Strøjer Madsen, Mogens Dilling-Hansen and Valdemar Smith (2003), Determinants of CEO and board turnover, Empirica, 28(3), 243-257.

Filatotchev, Igor, Mike Wright and Michael Bleaney (1999), Privatization, insider control and managerial entrenchment in Russia, Economics of Transition, 7(2), 481-504.

Frye, Timothy M. and Ichiro Iwasaki (2011), Government directors and business-state relations in Russia, European Journal of Political Economy, 27(4), 642-658.

Garvey, Gerald T. and Gordon Hanka (1999), Capital structure and corporate control: The effect of antitakeover statutes on firm leverage, Journal of Finance, 54(2), 519-546.

Gillan, Stuart L. and Laura T. Starks (2003), Corporate governance, corporate ownership, and the role of institutional investors: A global perspective, Journal of Applied Finance, 13(2), 4-22.

Gorton, Gary and Frank A. Schmid (2004), Capital, labor, and the firm: A study of German codetermination, Journal of the European Economic Association, 2(5), 863-905.

Granovetter, Mark S. (1973), The strength of weak ties, American Journal of Sociology, 78(6), 1360-1380.

Greene, William H. (2011), Econometric analysis (Seventh Edition), Prentice Hall: Boston and Tokyo.

Hackman, B. Katarina and Dexter C. Dunphy (1990), Managerial delegation, International Review of Industrial and Organizational Psychology, 5, 35-57.

Haleblian, Jerayr and Sydney Finkelstein (1993), Top management team size, CEO dominance, and firm performance: The moderating roles of environmental turbulence and discretion, Academy of Management Journal, 36(4) 844-863.

Her, M. Monica and Arvind Mahajan (2005), Family control, two-tier boards and firm performance: Lessons from the Taiwanese experience, Journal of Asia-Pacific Business, 6(2), 69-89.

Hopt, Klaus J. and Patrick C. Leyens (2004), Board models in Europe: Recent developments of internal corporate governance structures in Germany, the United Kingdom, France, and Italy, European Company and Financial Law Review, 1(2), 135-168.

Iontsev, M. (2002), Aktsionernoe obshchestvo: pravovye ocnoby. imushchestvennye otnosheniya upravlenie i kontroli. zashchita prav aktsionerov. Os'-89: Moscow. (in Russian)

Iwasaki, Ichiro (2007a), Corporate law and governance mechanism in Russia, In: Dallago, Bruno and Ichiro Iwasaki (eds.), Corporate restructuring and governance in transition 
economies, Palgrave Macmillan: Basingstoke, 213-249.

Iwasaki, Ichiro (2007b), Legal forms of joint stock companies and corporate behavior in Russia, Problems of Economic Transition, 50(5), 73-86.

Iwasaki, Ichiro (2007c), Enterprise reform and corporate governance in Russia: A quantitative survey, Journal of Economic Surveys, 21(5), 849-902.

Iwasaki, Ichiro (2008), The determinants of board composition in a transforming economy: Evidence from Russia, Journal of Corporate Finance, 14(5), 532-549.

Jensen, Michael C. (2000), A theory of the firm: Governance, residual claims, and organizational forms, Harvard University Press: Cambridge, Mass.

Johnson, James A. and Barton Wechsler (1990), The development of an interorganizational network in state government: Improved performance through action research, International Journal of Public Administration, 13(5), 689-706.

Jungmann, Carsten (2006), The effectiveness of corporate governance in one-tire and two-tire board systems: Evidence from the UK and Germany, European Company and Financial Law Review, 3(4), 426-474.

Kyrov, A. A. (2009), Kommentapii k federal'nomu zakonu ob aktsionernykh obshchestvakh, Prospekt: Moscow. (in Russian)

Lausten, Mette (2002), CEO turnover, firm performance and corporate governance: Empirical evidence on Danish firms, International Journal of Industrial Organization, 20(3), 391-414.

Li, Jiatao (1994), Ownership structure and board composition: A multi-country test of agency theory predictions, Managerial and Decision Economics, 15(4), 359-368.

Linck, James S., Jeffry M. Netter and Tina Yang (2008), The determinants of board structure, Journal of Financial Economics, 87(2), 308-328.

Madura, Jeff, Thanh Ngo and Ariel M. Viale (2012), Why do merger premiums vary across industries and over time? Quarterly Review of Economics and Finance, 52(1), 49-62.

Maitland-Walker, Julian (ed.) (2008), Guide to European company laws, third edition, Sweet and Maxwell: London.

Maury, Benjamin (2006), Corporate performance, corporate governance and top executive turnover in Finland, European Financial Management, 12(2), 221-248.

Mogilevskii, S. D. (2001), Organy upravleniya khozyaistvennymi obshchestbami: pravovoi aspect, Delo: Moscow. (in Russian)

O’Toole, Laurence J., Jr. (1997), Treating networks seriously: Practical and research-based agendas in public administration, Public Administration Review, 57(1), 45-52.

Radygin, Alexander (2006), Corporate governance, integration and reorganisation: The contemporary trends of Russian corporate groups, Economic Change and Restructuring, 39(3-4), 261-323.

Radygin, A. (2009), Rossiiskii rynok sliyanii i pogroshchenii: etapy, osobennosti, perspektivy, Voprosy Ekonomiki, (10), 23-45. (in Russian) 
Rubeko, G. L. (2007), Pravovoi status organov upravleniya aktsionernykh obshchestv, Statut: Moscow. (in Russian)

Rosstat (the Federal Statistical Service) (2005), Rossiskii statisticheskii ezhegodnik 2004, Rosstat: Moscow. (in Russian)

Shapkina, G. S. (2009), Primenenie aktsionerogo zakonodatel'stva, Statut: Moscow. (in Russian)

Schilling, Melissa A. and Corey C. Phelps (2007), Interfirm collaboration networks: The impact of large-scale network structure on firm innovation, Management Science, 53(7), 1113-1126.

Weisbach, Michael S. (1988), Outside directors and CEO turnover, Journal of Financial Economics, 20(1-2), 431-460.

Williamson, Oliver E. (1996), The mechanism of governance, Oxford University Press: New York and Oxford.

Xuan, Yuhai (2009), Empire-building or bridge-building? Evidence from new CEOs' internal capital allocation decisions, Review of Financial Studies, 22(12), 4919-4948.

Yakovlev, Andrei A. (2008), State-business relations and improvement of corporate governance, In: Dolgopyatova, Tatiana, Ichiro Iwasaki and Andrei A. Yakovlev (eds.), Organization and development of Russian business: A firm-level analysis, Palgrave Macmillan: Basingstoke, 284-306.

Yukl, Gary and Ping Ping Fu (1999), Determinants of delegation and consultation by managers, Journal of Organizational Behavior, 20(2), 219-232.

Yun, Hayong (2009), The choice of corporate liquidity and corporate governance, Review of Financial Studies, 22(4), 1447-1475.

van Ees, Hans, Theo J.B.M. Postma and Elmer Sterken (2003), Board characteristics and corporate performance in the Netherlands, Eastern Economic Journal, 29(1), 41-58. 
(a) Type I

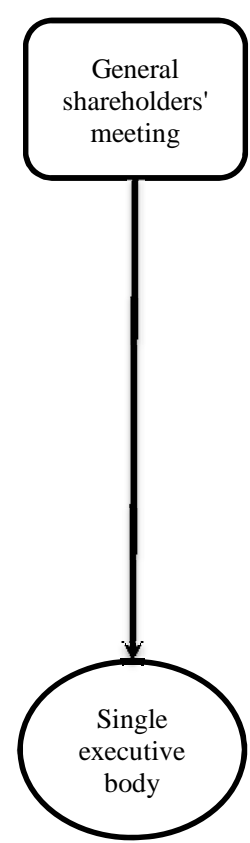

(b) Type II

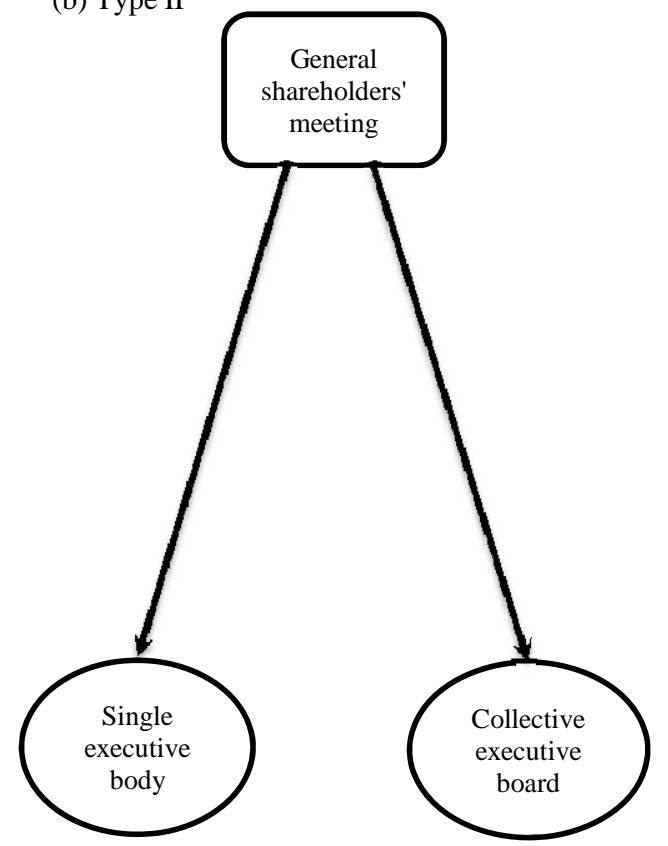

(c) Type III

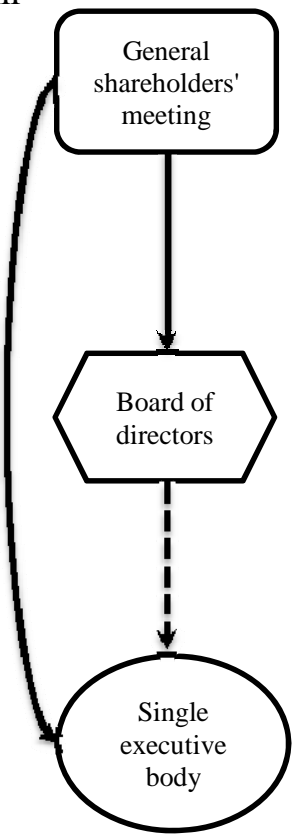

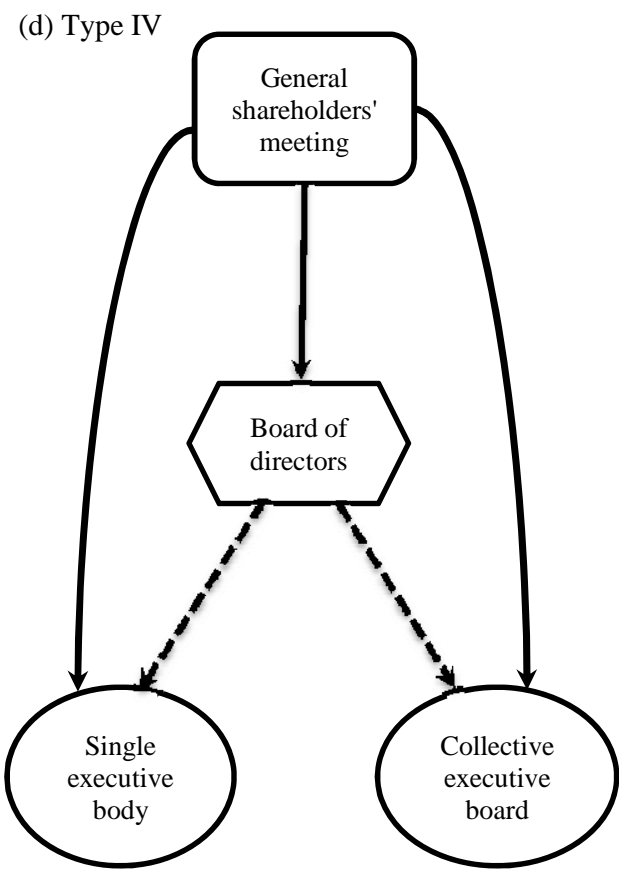

Figure 1. Possible types of corporate board systems of joint-stock companies in Russia

Note : This figure shows four possible combinations of a general shareholders' meeting, board of directors, and executive bodys for joint-stock companies in accordance with the Law of Joint-Stock Companies of the Russian Federation. An arrow indicates that the corporate organ at the starting point has the authority to appoint and dismiss members of the other organ at the end point. A dotted arrow denotes that the authority

relationship is in force only if the relevant provision is stipulated in the articles of incorporation. The law prohibits more than $25 \%$ of the board directorship from being represented by members of a collective executive

board not to allow them to become a majority force in the board of directors under a board system of Type IV. For more details, see Section 2 of the paper. 


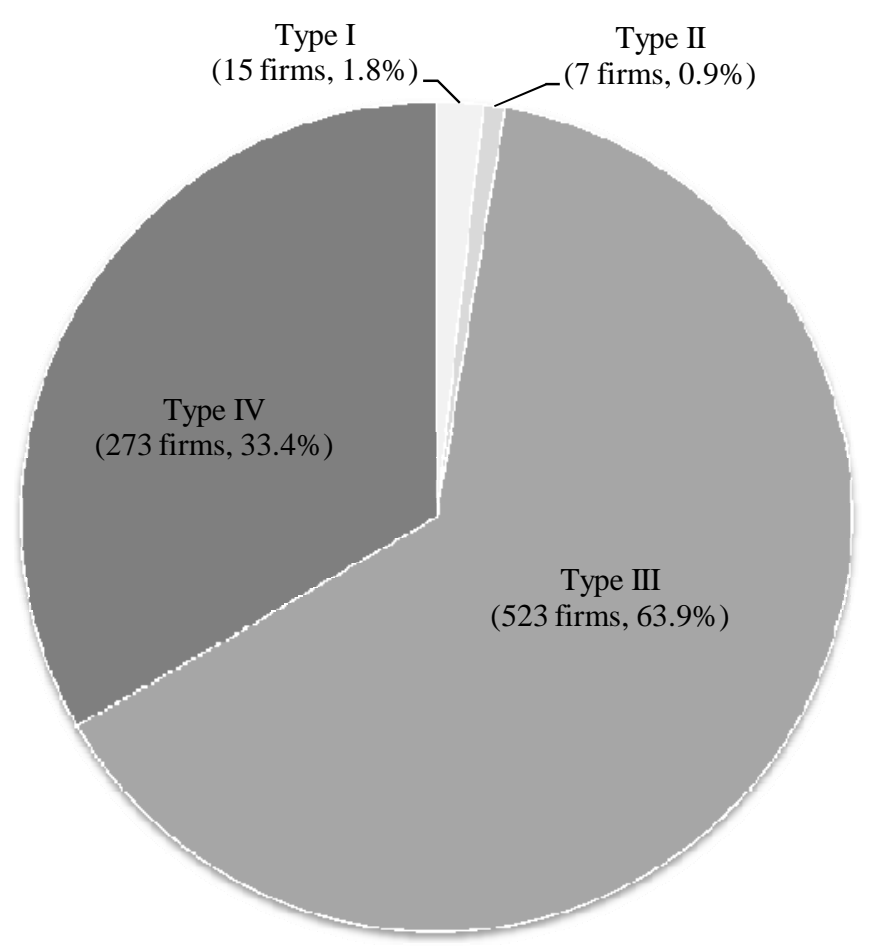

Figure 2. Breakdown of 818 joint-stock companies by board system

Note: The samples are Russian joint-stock companies that participated in the Japan-Russia joint enterprise survey conducted in 2005. 818 surveyed firms are classified according to the four types of corporate board system corresponding with Figure 1 .

\section{(Firms)}

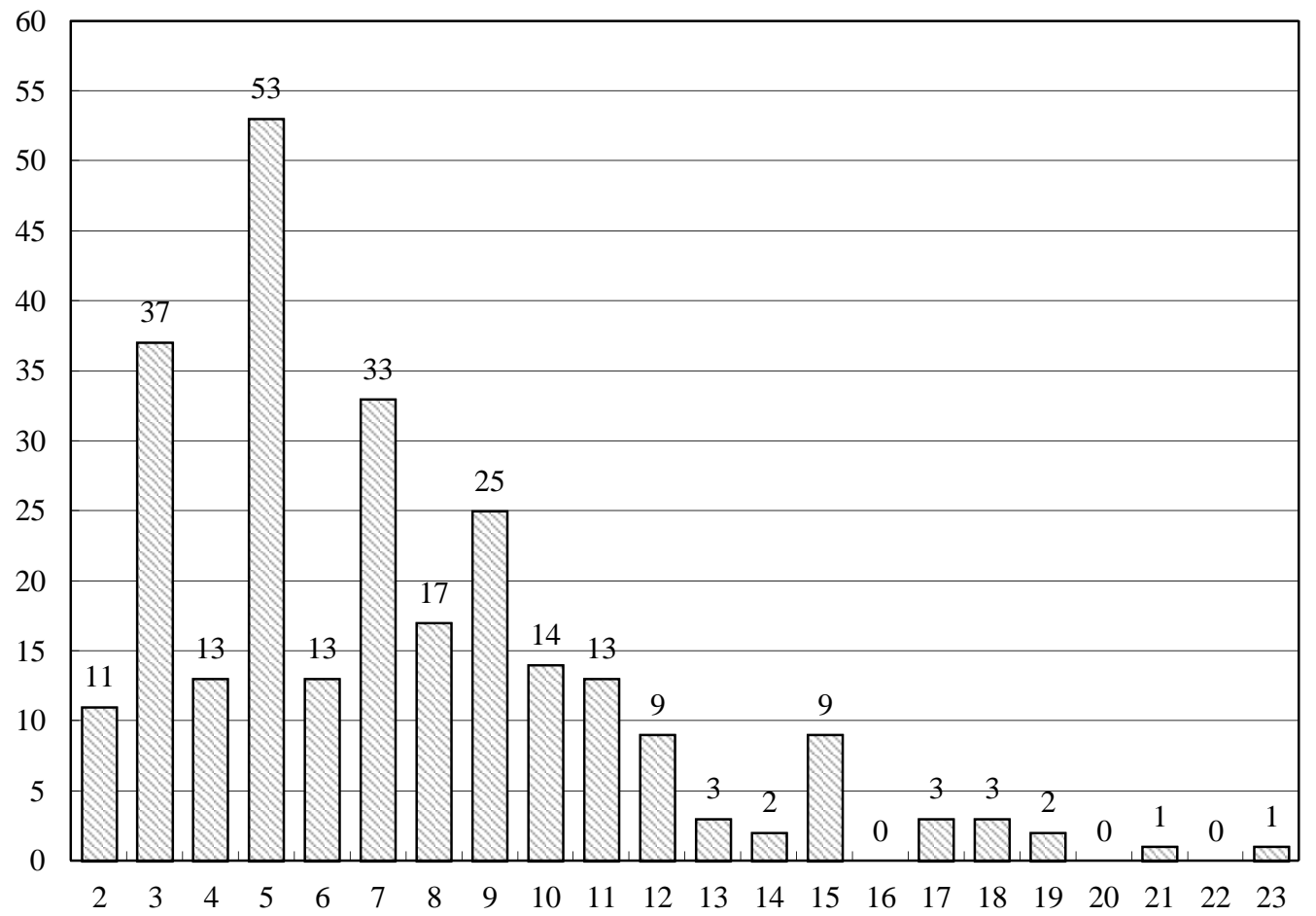

Size of the collective executive board (persons)

Figure 3. Size of the collective executive board in 262 joint-stock companies (frequency distribution) Note: The samples are Russian joint-stock companies that participated in the Japan-Russia joint enterprise survey conducted in 2005. The size of the collective executive board denotes the total number of board members. The basic statistics of the size of the collective executive board are as follows: mean: 7.25; standard deviation: 3.94; median: 7; skewness: 1.14; kurtosis: 4.37. 
Table 1. Industry-to-industry comparison of the proportion of companies with a collective executive board and board size

\begin{tabular}{lcc}
\hline & $\begin{array}{c}\text { Proportion of } \\
\text { companies with a } \\
\text { collective } \\
\text { executive board }\end{array}$ & $\begin{array}{c}\text { Size of the } \\
\text { collective } \\
\text { executive board }\end{array}$ \\
\hline $\begin{array}{l}\text { Industrial sector } \\
\text { Fuel and energy }\end{array}$ & 0.319 & 7.053 \\
Metallurgy (steel and non-ferrous metals) & 0.470 & 8.483 \\
Machine-building and metal working & 0.361 & 5.462 \\
Chemical and petrochemical & 0.361 & 7.227 \\
Wood, paper, and wood products & 0.364 & 8.700 \\
Light industry & 0.274 & 6.813 \\
Food industry & 0.294 & 7.067 \\
Construction materials & 0.217 & 5.303 \\
Communications sector & 0.286 & 7.455 \\
\hline & 0.600 & 8.500 \\
\hline
\end{tabular}


Table 2. Theoretical predictions of the impacts of firm organization and business activities o the choice and size of the collective executive board in the context of the Russian transition economy

$\begin{gathered}\text { Choice of the } \\ \text { collective }\end{gathered}$ collective
collive

executive board executive board

Ownership by outside investors

$+$

Ownership by management executives

Presence of the federal government as a shareholder

Affiliation with a business group through stock ownership

Internal promotion of top manager

Short tenure of top manager

Company size

Business diversification

Business internationalization

R\&D/innovation intensity

Fund procurement from the capital market and financial institutions

Selection of an open joint-stock company as the form of incorporatic

Establishment as a former state-owned (ex-municipal) privatized company

Establishment as a company spun off from a state-owned (municipal) company or a former state-owned (ex-municipal)

Note: This table summarizes the theoretical predictions of the impact of potential factors on the formation of a collective executive board in Russian firms on the basis of the discussion in Section 4 of the paper. The sign ' + ' denotes a positive correlation between a given factor and the probability of establishing a collective executive board and its membership size, '-,' for a negative correlation. The question mark, "?," means that the impact is unpredictable. 
Table 3. Definition and descriptive statistics of the variables used in empirical analysis, the univariate comparative analysis between firms with and without a collective executive board, and the correlation coefficients with the size of the collective executive board

\begin{tabular}{|c|c|c|c|c|c|c|c|c|c|c|}
\hline \multirow{2}{*}{ Definition of variable (variable name) } & \multicolumn{5}{|c|}{ Descriptive statistics } & \multicolumn{2}{|c|}{$\begin{array}{c}\text { Firms without a } \\
\text { collective executive } \\
\text { board }\end{array}$} & \multicolumn{2}{|c|}{$\begin{array}{l}\text { Firms with a collective } \\
\text { executive board }\end{array}$} & \multirow{2}{*}{$\begin{array}{l}\text { Correlation } \\
\text { coefficients with } \\
\text { the size of the } \\
\text { collective } \\
\text { executive board }\end{array}$} \\
\hline & Mean & S. D. & Median & Min. & Max. & $\begin{array}{c}\text { Mean/ } \\
\text { Proportion }\end{array}$ & Median & $\begin{array}{c}\text { Mean/ } \\
\text { Proportion }\end{array}$ & Median $^{\text {b }}$ & \\
\hline Ownership share of outside investors (OWNOUT) & 1.868 & 2.135 & 0 & 0 & 5 & 1.699 & 0.000 & $2.199^{* * * *}$ & $2.000^{* * *}$ & $0.221^{* * * *}$ \\
\hline Ownership share of the state (OWNSTA) & 0.479 & 1.168 & 0 & 0 & 5 & 0.353 & 0.000 & $0.722^{* * *}$ & $0.000^{* * *}$ & $0.155^{* *}$ \\
\hline Ownership share of the federal government (OWNFED) & 0.358 & 1.024 & 0 & 0 & 5 & 0.213 & 0.000 & $0.637^{* * * *}$ & $0.000^{* * *}$ & $0.213^{* * * *}$ \\
\hline Ownership share of regional and local governments (OWNREG) & 0.170 & 0.676 & 0 & 0 & 5 & 0.179 & 0.000 & 0.153 & 0.000 & -0.022 \\
\hline Ownership share of private investors (OWNPRI) & 1.495 & 2.009 & 0 & 0 & 5 & 1.402 & 0.000 & $1.672^{*}$ & $0.000^{*}$ & $0.199^{* * * *}$ \\
\hline Ownership share of commercial banks (OWNBAN) & 0.151 & 0.581 & 0 & 0 & 5 & 0.126 & 0.000 & 0.198 & $0.000^{* * *}$ & 0.035 \\
\hline Ownership share of investment funds and other financial institutions (OWNFIN) & 0.240 & 0.788 & 0 & 0 & 5 & 0.190 & 0.000 & $0.338^{* *}$ & $0.000^{* * *}$ & $0.155^{* *}$ \\
\hline Ownership share of non-financial corporate shareholders $(\mathrm{WNCOR}$ ) & 0.930 & 1.665 & 0 & 0 & 5 & 0.926 & 0.000 & 0.936 & 0.000 & $0.166^{* *}$ \\
\hline Ownership share of foreign investors $(O W N F O R$ ) & 0.354 & 1.032 & 0 & 0 & 5 & 0.335 & 0.000 & 0.392 & $0.000^{* * *}$ & 0.070 \\
\hline Large managerial shareholder dummy (MANSHA) & 0.479 & 0.500 & 0 & 0 & 1 & 0.500 & 0.500 & 0.439 & 0.000 & $-0.1366^{* *}$ \\
\hline Business group member dummy (GROFIR) & 0.392 & 0.489 & 0 & 0 & 1 & 0.336 & 0.000 & $0.500^{\mathrm{Ht}}$ & $0.500^{* * *}$ & 0.067 \\
\hline Core business group member dummy GROCOR) & 0.054 & 0.226 & 0 & 0 & 1 & 0.052 & 0.000 & 0.057 & 0.000 & -0.033 \\
\hline Business group affiliation dummy (GROAFF) & 0.337 & 0.473 & 0 & 0 & 1 & 0.284 & 0.000 & $0.439 \mathrm{H+t}$ & $0.000^{* * *}$ & 0.068 \\
\hline Dummy for firms with an internally promoted top manager (NSCEO) & 0.586 & 0.493 & 1 & 0 & 1 & 0.581 & 1.000 & 0.595 & 1.000 & -0.031 \\
\hline Dummy for firms with a newly appointed top manager (NEWCEO) & 0.388 & 0.488 & 0 & 0 & 1 & 0.381 & 0.000 & 0.400 & 0.000 & 0.005 \\
\hline Total number of employees (COMSIZ) & 1893.250 & 5589.402 & 465 & 106 & 74000 & 1306.528 & 400.000 & $3016.404^{* * *}$ & $832.500^{* * *}$ & $0.252^{* * *}$ \\
\hline Number of business lines (BUSLIN) & 2.154 & 2.060 & 1 & 1 & 12 & 1.973 & 1.000 & $2.502^{* * * *}$ & $1.000^{* * *}$ & $0.155^{* *}$ \\
\hline Share of exports in total sales (EXPSHA) & 0.877 & 1.198 & 0 & 0 & 5 & 0.893 & 0.000 & 0.846 & 0.000 & 0.041 \\
\hline Dummy for the development of new products or services in 2001-2004 (NEWPRO) & 0.623 & 0.485 & 1 & 0 & 1 & 0.568 & 1.000 & $0.726^{\mathrm{t+t}}$ & $1.000^{* * *}$ & 0.045 \\
\hline Dummy for firms that issued shares or bonds in the overseas or domestic stock exchange(IARFIN) & 0.133 & 0.340 & 0 & 0 & 1 & 0.078 & 0.000 & $0.240^{\mathrm{Ht}}$ & $0.000^{* * *}$ & $0.255^{* * *}$ \\
\hline Firms that used bank credits and their average lending period (BANCRE) & 2.529 & 1.455 & 3 & 0 & 5 & 2.393 & 3.000 & $2.789^{* * *}$ & $3.000^{* * *}$ & 0.024 \\
\hline Open joint-stock company dummy (OPECOM) & 0.675 & 0.469 & 1 & 0 & 1 & 0.629 & 1.000 & $0.7644^{\mathrm{Ht}}$ & $1.000^{* * *}$ & 0.004 \\
\hline Dummy for former state-owned (ex-municipal) privatized companies (RICOM) & 0.697 & 0.460 & 1 & 0 & 1 & 0.688 & 1.000 & 0.714 & 1.000 & -0.006 \\
\hline$($ SPIOFF $)$ & 0.096 & 0.294 & 0 & 0 & 1 & 0.099 & 0.000 & 0.089 & 0.000 & 0.014 \\
\hline
\end{tabular}

Note: This table presents the definition, descriptive statistics, and data source of variables used in the empirical analyses, results from the univariate comparative analysis between firms with and without a collective executive board, and the correlation coefficients with the size of the collective executive board measured by the total number of board members. The samples are Russian joint-stock companies that participated in a Japan-Russia joint enterprise survey conducted in 2005. The number of business lines (BUSLIN) originates in the SKRIN open database. All other variables were created on the basis of the results of the joint enterprise survey. The natural logarithm $C$ COMSIZ is used in the regression analysis.

The following are the supplementary variable definitions: "Ownership share" means an ownership share rated on the following 6-point scale: 0: 0\%; 1: 10.0\% or less; 2: 10.1 to 25.0\%; 3: 25.1 to 50.0\%; 4: 50.1 to 75.0\%; 5: 75.1 to 100.0\% 3 WNOUT,

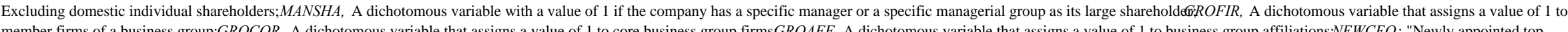
member firms of a business group; GROCOR, A dichotomous variable that assigns a value of 1 to core business group firms $G R O A F F$, A dichotomous variable that assigns a value of 1 to business group affiliations; $N E W C E O$ : "Newly appointed top manager" denotes a top manager (CEO, company president, or general director) appointed during the period from 2001 to 2004 USLIN, A proxy for the level of business diversification measured by the Russian All-Union Classifier of the National Econom Branches two-digit classification; EXPSHA, "Share of exports in total sales" falls under one of the following 6 categories: 0: 0\%; 1: 10\% or less; 2: 10.1 to 25.0\%; 3: 25.1 to 50.0\%; 4: 50.1 to 75.0\%; 5: More than 75\%;BANCRE, "Firms which used bank credits and their average lending period" fall under one of the following 6 categories: 0: Did not use any bank credits during the period from 2001 to 2004; 1: Used bank credits and their average lending period was less than 3 months; 2: Used bank credits and their average lending period ranged from 3 months to less than 6 months; 3: Used bank credits and their average lending period ranged from 6 months to less than one year; 4: Used bank credits and their average lending period ranged from one year to less than

3 years; 5: Used bank credits and their average lending period was more than 3 year
**** and $* *$ denote statistical significance at the $1 \%$ and $5 \%$ levels, respectively, according to the test (or Welch test if the $F$ test on the equality of variances rejects the null hypothesis that the population variances are equal) in terms of the differences in the means between firms with a collective executive board and those without one. $++\dagger$ denotes statistical significance at the $1 \%$ level according to the Chi-square $\left(^{2}\right)$ test in terms of the differences in the proportion between firms with a collective executive board and those without one.

${ }^{*} * * *$, **, and * denote statistical significance at the $1 \%, 5 \%$, and $10 \%$ levels, respectively, according to the Wilcoxon rank sum test in terms of the differences between firms with a collective executive board and those without one.

${ }^{\mathrm{C}}$ Relevant only to firms with a collective executive board. ${ }^{* * *}$ and ${ }^{* *}$ denote that the correlation coefficients are statistically significant at the $1 \%$ and $5 \%$ levels, respectively. 
Table 4. Determinants of the choice of the collective executive board: Probit model estimation

Dependent variable
Model
Ownership by outside investors $(O W N O U T)(+)$
Ownership by the state $($ OWNSTA $)(+)$
Ownership by the federal government $($ OWNFED) $(+)$
Ownership by regional and local governments $(O W N R E G)(+$

Ownership by private investors $(O W N P R I)(+)$

Ownership by commercial banks $(O W N B A N)(+)$ Choice of the collective executive board (COLEXE)

Ownership by other financial institutions $($ OWNFIN) $(+)$

\begin{tabular}{ccc}
{$[1]$} & {$[2]$} & {$[3]$} \\
\hline-0.002 & & \\
$(0.03)$ & & \\
& $0.102^{* *}$ & \\
& $(0.05)$ & \\
& & $0.132^{* *}$ \\
& & $(0.06)$ \\
& & -0.014 \\
& & $(0.09)$
\end{tabular}

Ownership by non-financial corporate shareholders $(O W N C O R)(+)$

$(0.03)$

Ownership by foreign investors $(O W N F O R)(+)$

Large managerial shareholding (MANSHA) (-)

Business group membership $($ GROFIR $)(+)$

Business group core firm $($ GROCOR $)(+)$

Business group affiliated firm (GROAFF) $(+)$

Internally promoted $\mathrm{CEO}($ INSCEO $)(+)$

Newly appointed CEO $($ NEWCEO $)(+)$

Company size (COMSIZ) $(+)$

Business diversification (BUSLIN) $(+)$

Business internationalization $($ EXPSHA $)(+)$

$\mathrm{R} \& \mathrm{D}$ and innovation intensity $(N E W P R O)(+)$

Fund procurement from capital markets $(M A R F I N)(+)$

Use of bank credits $(B A N C R E)(+)$

Selection of an open joint-stock company $(O P E C O M)(+)$

Establishment as a privatized company $($ PRICOM $)(+)$

Spin off from a state-owned (municipal) enterprise or a privatized company $(\mathrm{SPIOFF})(+)$

Const.

$\begin{array}{lll} & & (0.07) \\ 0.043 & 0.035 & 0.007 \\ (0.13) & (0.13) & (0.13) \\ 0.394^{* * *} & 0.437^{* * *} & 0.445^{* * *} \\ (0.14) & (0.14) & (0.14)\end{array}$

$-0.002$

[4]

$(0.03)$

0.174

$(0.13)$

0.111

$(0.07)$

$-0.045$

$(0.04)$

$-0.127^{*}$

$(0.07)$

0.007

0.043

$(0.32)$

$\begin{array}{llll}(0.13) & (0.13) & (0.13) & (0.13)\end{array}$

$\begin{array}{llll}-0.188 & -0.153 & -0.166 & -0.191\end{array}$

$\begin{array}{cccc}(0.13) & (0.13) & (0.13) & (0.13) \\ 0.230^{* * *} & 0.229^{* * *} & 0.241^{* * *} & 0.228\end{array}$

$\begin{array}{llll}(0.06) & (0.06) & (0.07) & (0.06)\end{array}$

$\begin{array}{llll}0.017 & 0.013 & 0.018 & 0.017\end{array}$

$\begin{array}{llll}(0.03) & (0.03) & (0.03) & (0.03)\end{array}$

$-0.121^{* *} \quad-0.127^{* *} \quad-0.128^{* *}-0.121^{* *}$

$\begin{array}{llll}(0.06) & (0.06) & (0.06) & (0.06)\end{array}$

$0.458^{* * *} \quad 0.468^{* * *} \quad 0.489^{* * *} \quad 0.458^{* * *}$

$\begin{array}{llll}(0.13) & (0.13) & (0.13) & (0.13)\end{array}$

$\begin{array}{llll}0.171 & 0.173 & 0.146 & 0.174\end{array}$

$\begin{array}{llll}(0.23) & (0.23) & (0.25) & (0.23)\end{array}$

$\begin{array}{llll}0.073^{*} & 0.083^{*} & 0.079\end{array}$ * 0.073 *

$\begin{array}{llll}(0.04) & (0.04) & (0.05) & (0.04)\end{array}$

$0.474^{* * *} \quad 0.463^{* * *} \quad 0.477^{* * *} \quad 0.472^{* * *}$

$\begin{array}{llll}(0.13) & (0.13) & (0.14) & (0.13)\end{array}$

$\begin{array}{llll}0.077 & 0.059 & 0.033 & 0.077\end{array}$

$\begin{array}{llll}(0.17) & (0.17) & (0.17) & (0.17)\end{array}$

$\begin{array}{llll}-0.043 & -0.067 & -0.098 & -0.047\end{array}$

$\begin{array}{llll}(0.25) & (0.25) & (0.26) & (0.25)\end{array}$

$-2.729^{* * *} \quad-2.802^{* * *}-2.856^{* * *}-2.722^{* * *}$

$\begin{array}{llll}(0.50) & (0.50) & (0.51) & (0.51)\end{array}$

Industry dummy

\begin{tabular}{rrrr} 
Yes & Yes & Yes & Yes \\
\hline 561 & 558 & 558 & 561 \\
0.15 & 0.16 & 0.17 & 0.15 \\
$05.30^{* * *}$ & $-301.07^{* * *}$ & -296.68 & -305.27 \\
$01.25^{* * * *}$ & $107.80^{* * *}$ & $114.24^{* *}$ & $102.71^{* *}$
\end{tabular}

Pseudo $\mathrm{R}^{2}$

Log likelihood

$101.25^{* * *} \quad 107.80 *$

$114.24^{* * *}$

Note : This table contains the results from the Probit regression analysis of the choice of the collective executive board on the variables reflecting firm organization and business activities. The samples are Russian joint-stock companies that participated in a Japan-Russia joint enterprise survey conducted in 2005. The dichotomous variable that assigns a value of 1 to firms that establish a collective executive board is used as the dependent variable. Table 3 provides the detailed definitions and descriptive statistics of the independent variables. The predicted signs are indicated in parentheses following the abbreviation of the independent variables. Standard errors are computed using White's heteroskedasticityconsistent estimator and given in parentheses beneath the regression coefficients. ${ }^{* *},{ }^{* *}$, and $*$ denote statistical significance at the $1 \%, 5 \%$, and $10 \%$ levels, respectively. 
Table 5. Determinants of the size of the collective executive board: Sample selection model estimation

\begin{tabular}{l} 
Dependent variable \\
\hline Model \\
Ownership by outside investors $($ OWNOUT) $(+)$
\end{tabular}

Ownership by the federal government $(O W N F E D)(+)$ Size of the collective executive board (COLSIZ)

\begin{tabular}{|c|c|c|c|}
\hline [1] & {$[2]$} & [3] & [4] \\
\hline 0.023 & & & 0.023 \\
\hline
\end{tabular}

$(0.02)$

0.031

$(0.02)$

Ownership by regional and local governments $(O W N R E G)(+)$

$(0.02)$

Ownership by regional and local governments $(O W N R E G)(+)$

Ownership by private investors $(O W N P R I)(+)$

Ownership by commercial banks $(O W N B A N)(+)$

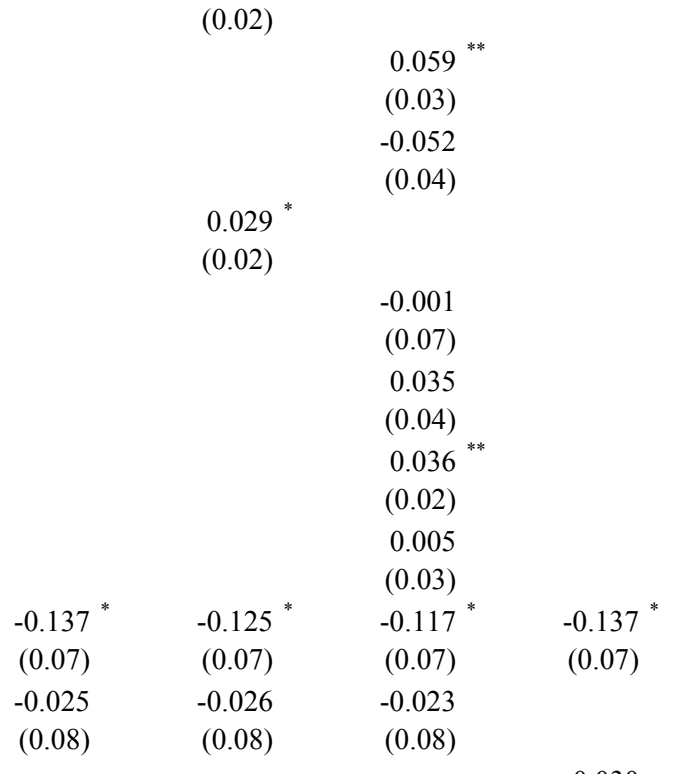

Ownership by other financial institutions $(O W N F I N)(+)$

Ownership by non-financial corporate shareholders $(O W N C O R)(+)$

Ownership by foreign investors $(O W N F O R)(+)$

Large managerial shareholding (MANSHA) (-)

Business group membership (GROFIR) $\left(^{+}\right)$

Business group core firm $($ GROCOR $)(+)$

Business group affiliated firm $(G R O A F F)(+)$

Internally promoted CEO (INSCEO) $(+)$

Newly appointed CEO $($ NEWCEO $)(+)$

Company size (COMSIZ) $(+)$

Business diversification (BUSLIN) $(+)$

Business internationalization $($ EXPSHA $)(+)$

$\mathrm{R} \& \mathrm{D}$ and innovation intensity $(N E W P R O)(+)$

Fund procurement from capital markets $($ MARFIN) $(+)$

Use of bank credits $(B A N C R E)(+)$

Selection of an open joint-stock company $($ OPECOM $)(+)$

Establishment as a privatized company (PRICOM) (?)

Spin off from a state-owned (municipal) enterprise or a privatized company (SPIOFF) (?)

Const.

\begin{tabular}{lrrrr} 
Industry dummy & Yes & Yes & Yes & Yes \\
\hline $\mathrm{N}$ & 557 & 554 & 554 & 557 \\
Log likelihood & -392.66 & -387.04 & -380.30 & -392.55 \\
Wald test $\left(\chi^{2}\right)$ that all coefficients are zero & $82.33^{* * *}$ & $79.11^{* * *}$ & 82.31 & $84.72^{* * * *}$ \\
$\rho$ & -0.05 & -0.08 & -0.11 & -0.04 \\
Wald test $\left(\chi^{2}\right)$ of the independence of equations & 0.02 & 0.06 & 0.11 & 0.01 \\
\hline
\end{tabular}

Note: This table contains the results from the Heckman two-step regression analysis of the size of the collective executive board on the variables reflecting firm organization and business activities. The samples are Russian joint-stock companies that participated in a Japan-Russia joint enterprise survey conducted in 2005. The dependent variable is the log of total number of collective executive board members by adding 1 . In the first stage of estimation, a probit model is used to predict the probability of establishing a collective executive board. The number of uncensored observations is 184 at the second stage of estimation. Table 3 provides the detailed definitions and descriptive statistics of the independent variables. The predicted signs are indicated in parentheses following the abbreviation of the independent variables. The question mark, "?," denotes that the impact is unpredictable. Standard errors are computed using White's heteroskedasticity-consistent estimator and given in parentheses beneath the regression coefficients. The Wald test of the independence of equations tests the null hypothesis that $\rho=0 .{ }^{* * *}, * *$, and * denote statistical significance at the $1 \%, 5 \%$, and $10 \%$ levels, respectively. 